\title{
Performance-Based Fire Safety in an Existing Residential Multi-Story Building in Surakarta
}

\author{
Wahyu Sujatmiko', Yulia Rahmawati², \\ Ramadan Pratama Gumilar ${ }^{3}$ \\ $1,2,3$ Research Institute for Housing and Human Settlements, Agency for \\ R\&D, Ministry of Public Works and Housing, Indonesia
}

\author{
Article History \\ Received : 04 September 2020 \\ Accepted : 30 September 2020 \\ Published : 05 October 2020
}

\begin{abstract}
Multi-story residential building for low-income communities, which is one of the vertical housing forms programmed by the current Indonesian government, must meet the requirements for the proper functioning of the building, including safety from fire hazards. Fulfillment of fire safety is carried out through three fire protection systems, namely: passive fire protection systems, active fire protection systems, and fire safety management. The problem is whether the safety of the fire hazard in the existing low-income residential multi-story building is still fulfilled or not. In this paper, the study on performance bases fire protection in the low-income residential multi-story building in Surakarta city, Indonesia, namely Rusunawa A, will be presented. This building has a height of 5 floors, with a semi-double-loaded building mass with a vacuum in the middle. The existing condition of the building indicates that an active fire protection system in the form of a fire pump system for a fire hydrant system is damaged due to corrosion of the pipes caused by salt or corrosive water. The performance of the building fire safety studies by simulating Available Safety Egress Time (ASET) and Required Safety Egress Time (RSET). Both of these simulations were carried out to get the minimum level of fire protection that must be provided so that the building still meets the minimum requirements for safety. ASET simulations use Thunderhead Pyrosim software and RSET simulations using Thunderhead Pathfinder software. From the results of this study, we can estimate the potential for fire hazards, the time of growth of fire hazards, the time needed for evacuation of residents, and the results of evaluating compliance with existing conditions and additional fire protection proposals needed to overcome the lack of existing conditions.
\end{abstract}

Keywords: Fire survey; Fire modeling; Multi-story residential building; Performance-based fire protection; Simulation

\section{Introduction}

The Ministry of Public Works and Housing, through the Multi-Story Residential Building Directorate (Direktorat Rumah Susun), has the task of constructing the multi-story residential buildings. The Directorate has tried to make several types of residential multi-story buildings for low-income communities (Ministry of Public Works and Housing Indonesia, 2019).

Correspondence: Wahyu Sujatmiko

Research Institute for Housing and Human Settlements, Agency for R\&D, Ministry of Public Works and Housing, Indonesia

E-mail: jtwsmiko@gmail.com
The building must fulfill the proper building functions, including fire safety aspects. Fire safety in the building is fulfilled by three aspects of the fire protection systems, those are passive fire protection systems, active fire protection systems, and fire safety management.

Active fire protection systems, such as fire pump systems, hydrant systems, alarm systems, require excellent and continuous maintenance to function along with the age of the building. It is often found that this active fire protection system is not functioning or has been damaged. Passive fire protection systems have an important role in providing adequate ASET dan RSET in fire safety of the building, 
Performance-Based Fire Safety in an Existing Residential Multi-Story Building in Surakarta Wahyu Sujatmiko, Yulia Rahmawati, Ramadan Pratama Gumilar especially if the active fire protection systems failed or damaged. The planning stage is the key for architects and engineers to create a building design that is safe from fire hazards as passive fire protection systems.

The problem is whether the existing multi-story residential building in Indonesia meet the fire safety requirements with that existing condition of fire protection systems. This paper provides the study results of performance-based fire safety in one of the existing multi-story residential building in Surakarta city, namely Rusunawa A. This performance-based fire safety study in multi-story residential building aims to assess the level of fire safety in the existing building, provide an improvement proposal for the existing building, and provide an overview of the importance of fire aspect consideration in designing a new building.

\section{Literature Review}

The previous study (Sujatmiko et al, 2014) in high-rise multi-story residential building has shown that the safety conditions in need indeed require attention. The basic study of the performance of building fire safety studies is done by simulating ASET and RSET. ASET is the time of the safety exit available, while the RSET is required when the safety way out. Both of these simulations are carried out to obtain the minimum level of fire protection that must be provided so that the building still meets the minimum requirements for safety. The study was conducted using a performance-based approach.

The performance-based approach is a natural challenge as Asia-Oceania regions economic growth (Chow, 2015). Indonesia must be encouraged to play an increasingly active role in the field of performance bases, as well as to further enhance existing prescriptive standards, especially those relating to safety evacuation (Sujatmiko, 2016). Other literature shows the importance of basic performance studies related to evacuation safety in multistory residential buildings (Mcdermott, 2010; Li, 2017; Fang, 2012).

Other problems are related to housing fires. In Indonesia, there are no regulations regarding the maximum fire load. High fire loads for homes abroad have been tried to be managed
(Liu, 2014). The problem in Indonesia is, in addition to the varying amount of fire, the most important thing is the content of hazardous materials that exist. Existing studies show that occupancy can be very high because there are parking lots (Spearpoint, 2015) and also, there are many materials that have been switched from wood-based to plastic-based (Mckenna, 2019).

Another important thing related to performancebased studies, more and more simulation studies using CFD (Computational Fluid Dynamics) software. CFD is one tool for performance-based studies (Deckers, 2013). Fire scenarios for entering CFD simulation software need to refer to existing conditions which can be found in several studies (Xin, 2013; Baalisampang, 2017; Blocken, 2009).

\section{Methodology}

This study uses several methods, namely: building a survey for objects studied, fire simulations to assess ASET, and evacuation simulations to determine RSET, and evaluate fire safety compliance requirements.

\section{Building Survey}

The survey was conducted for a multi-story residential building in the city of Surakarta. This building is given notation as a Rusunawa A (Figure $1 \& 2$ ). Observations are made on the existing fire conditions, including building geometry, passivity, active systems, and management. The survey was conducted related to the 2018 Settlement Research and Development Center activities (Ministry of Public Works and Housing Indonesia, 2018).

Table 1. Object of Study

\begin{tabular}{ll}
\hline Name & \multicolumn{1}{c}{ Specification } \\
\hline Object Name & $\begin{array}{l}\text { Rusunawa A } \\
\text { Location }\end{array}$ \\
Year of Constructions & 2010 \\
Number of Towers & 2 (Tower A \& Tower B) \\
Number of floors & 5 \\
Floor designation & $1^{\text {st }}$ Floor: Parking Area \\
& $2^{\text {nd }}$ Floor $-5^{\text {th }}$ Floor: Typical Unit \\
Number of staircases & 3 \\
Number of units & 80 Units per Tower (@20 Units per Floor) \\
Typology & Semi Single Loaded (with Void) \\
\hline
\end{tabular}

Source: Author 
Figure 1. Aerial View or Site Plan of Rusunawa A Residential Multi-Story Building

Source: Google Earth

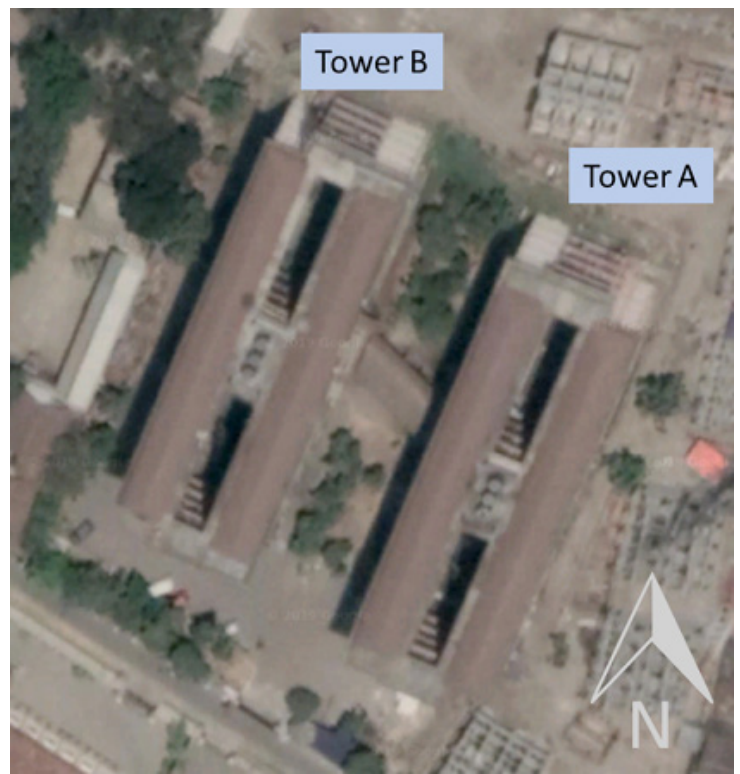

Figure 2. Existing Exterior View of Rusunawa A Residential Multi-Story Building

Source: Author

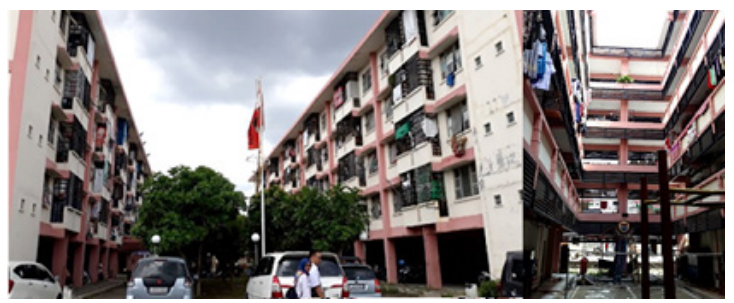

In Figure 3 until Figure 6, presented the results of the observation of the existing conditions of the fire load and the availability of fire protection.

Figure 3. Fire load or arrangement of combustible material in the exterior unit of the building

Source: Author

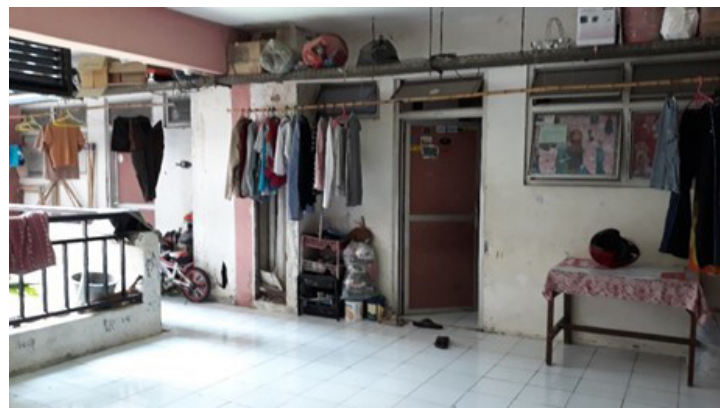

Figure 4. Some fire load or arrangement of combustible material in the interior unit of the building

Source: Author

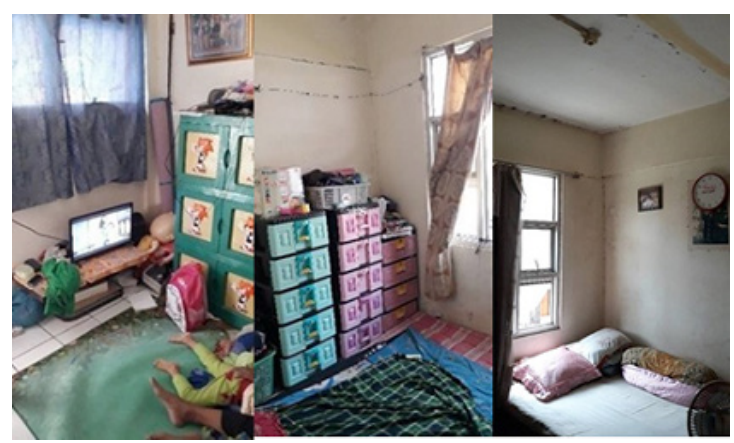

Figure 5. The distance of the location of the multi-story residential building with the fire service Source: Google Map

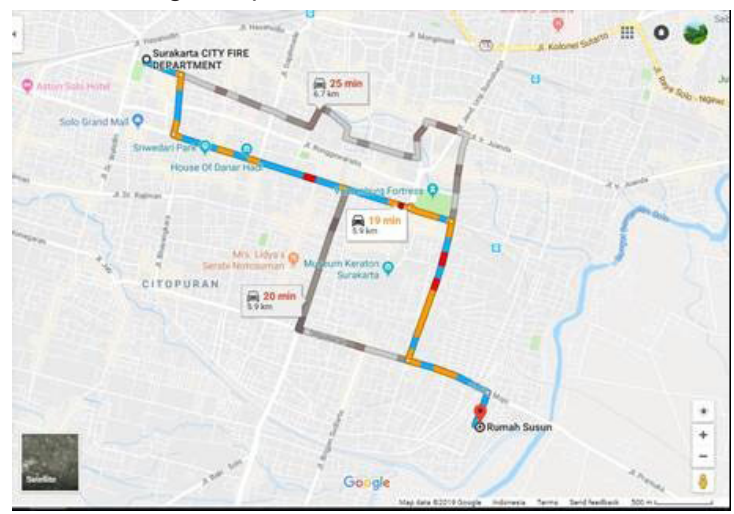

Figure 6. Fire Protection Conditions (Fire Pump \& Portable Extinguisher)

Source: Author

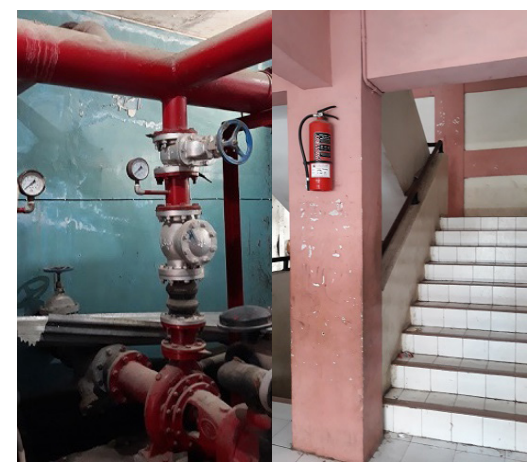

\section{Fire Simulation}

The building model is presented in Figure 7. The fire model is designed with several fire scenarios. As a source of fire, there are three types of fire curves, consisting of fabric (curtain), wardrobe (wardrobe), and foam mattress (mattress). The data for fire curves refer to (Kim, 2008). The combined results of all three types of material when burned are all an HRR curve with a peak of $5698 \mathrm{~kW}$ at 164 seconds and $2067 \mathrm{~kW}$ at 738 seconds for no-wind conditions. With the presence of 0.5 $\mathrm{m} / \mathrm{s}$ wind, the peaks are obtained at $5725 \mathrm{~kW}$ 
at 165 seconds and $2036 \mathrm{~kW}$ at 740 seconds. With the presence of $2 \mathrm{~m} / \mathrm{s}$ wind, the peaks are obtained at $5634 \mathrm{~kW}$ at 167 seconds and 1821 $\mathrm{kW}$ at 746 seconds.

\section{Evacuation Simulation}

ASET and RSET can be calculated using computer modeling and simulation to analyze the performance-based fire safety of building. The modeling can be used to maximizing the planning or designing stage of a building. For an existing building, the modeling can be used to evaluate the existing fire protection system.

Evacuation simulation parameter:

a. Simulation object is Rusunawa A, Surakarta, as shown in Fig. 8.

b. Modeling is made using Pathfinder software in $1: 1$ ratio.

c. 4 occupants per unit residential consisting of young men and women.

d. 3 exit staircases.

Figure 7. (a) 3D model, (b) floor plan, and (c) a typical unit of Rusunawa A residential building. Source: Author

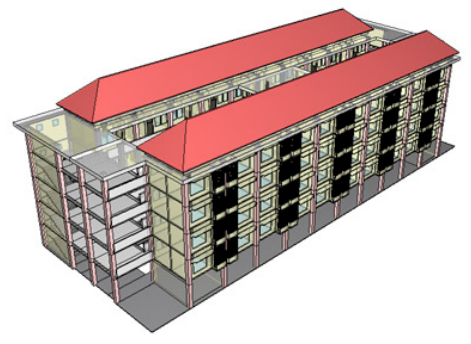

(a)

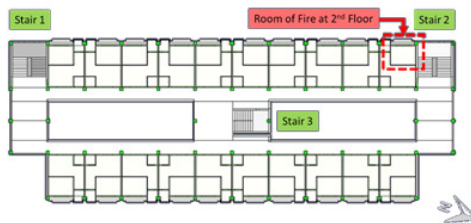

(b)

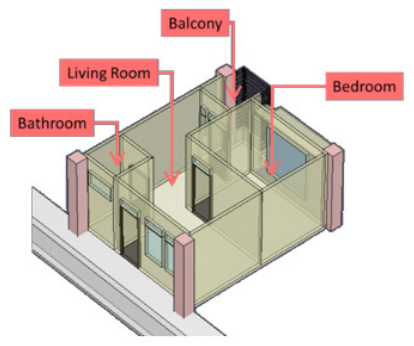

(c)

Chart 1. The shape of the fire curve, for (a) mattress, (b) wardrobe, (c) curtain, and (d) combination of the three materials. The simulation was carried out with three wind conditions, namely without wind, wind $0.5 \mathrm{~m} / \mathrm{s}$, wind $2 \mathrm{~m} / \mathrm{s}$, and 5 $\mathrm{m} / \mathrm{s}$ in the picture submitted for conditions without wind.

Source: Author

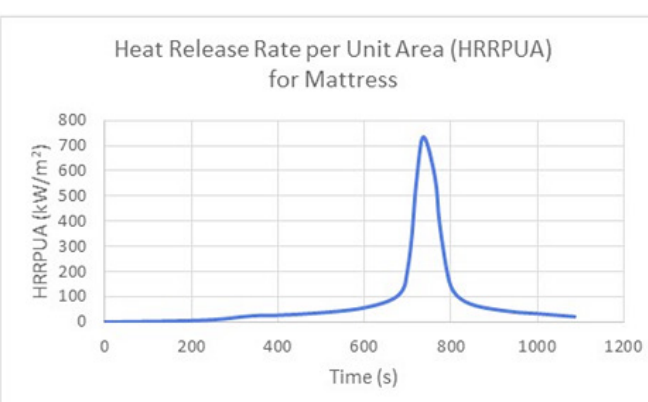

(a)

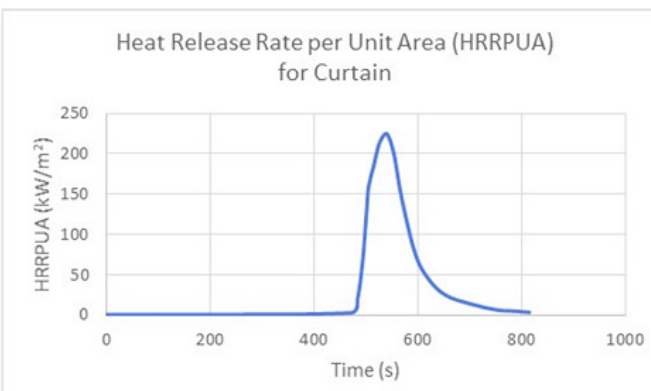

(c)

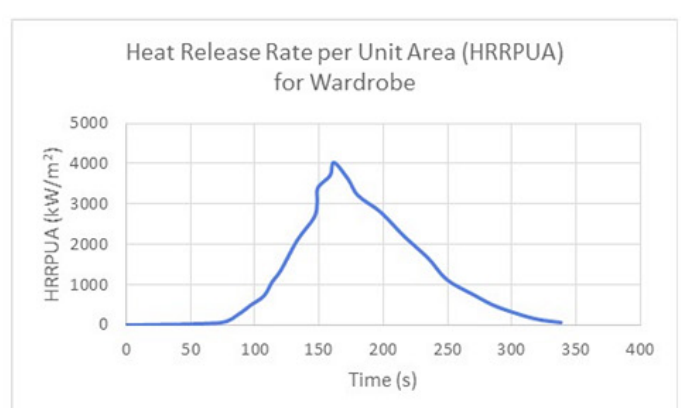

(b)

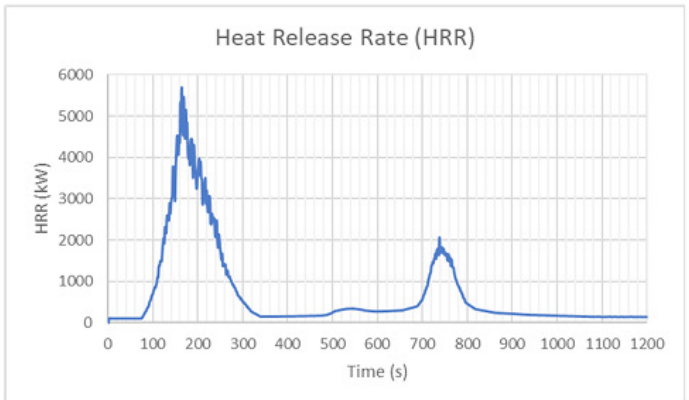

(d) 
Figure 8. Evacuation Modeling

Source: Author

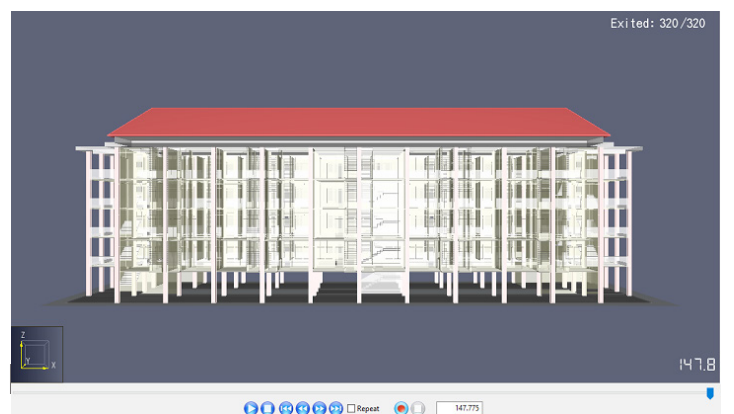

\section{Existing Condition for Fire Safety}

Observations show that: a. The fire protection system in the form of a fire hydrant system does not function. One of the causes of malfunction is any broken pipes. b. The alarm system is not functioning correctly. c. The only active fire protection system that works is APAR (fire extinguisher). d. There is no setting of fire load, and residents can store items that can be burned so that it can become a fire burden, there are no settings.

\section{Results of Fire Simulations}

Simulation results are presented in Fig 9 to 14, Chart 2 to 3, and Table 3: displayed simulation results, both numbers, and visual images and graphs. Reviews are given after viewing the images.

Figure 9. Room of Fire Temperature Distribution at $167 \mathrm{~s}$ Source: Author

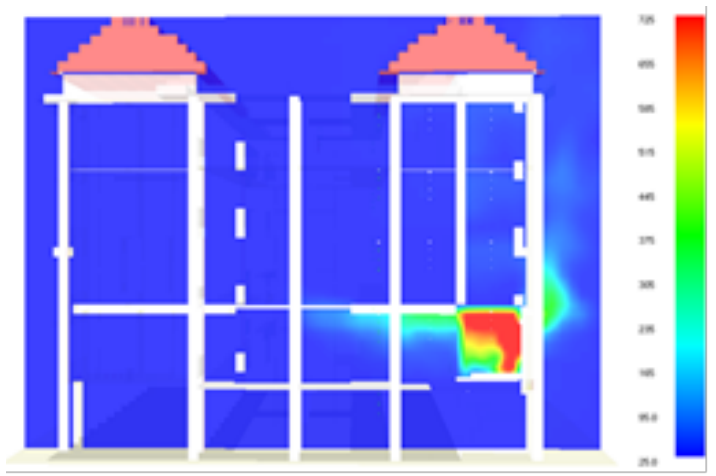

Figure 10. Temperature distribution at the room of fire (occupied level)

Source: Author

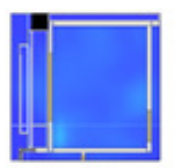

$t=60 \mathrm{~s}$

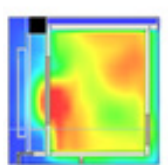

$t=240$ s

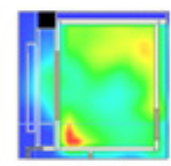

$t=120$ s

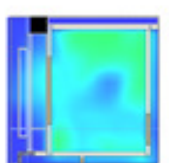

$t=300$ s

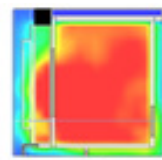

$t=180$ s

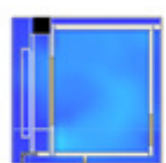

$t=360$ s
Fire simulation using Pyrosim and FDS shows:

a. The higher wind speed causes a greater fire development so that the temperature and the toxic gas Fractional Effective Dose (FED) in the fire compartment reach an untenable condition in a shorter time. The spread of smoke to various parts of the building is faster, thus inhibiting and slowing the evacuation of occupants.

b. In the low wind speed scenario, the smoke of fire grows vertically through the opening of windows and door headed to the corridor and then leads to the void in the middle of the building. The smoke easily fills the residential units above the fire compartment and the north staircase. The temperature and toxic gas FED in the residential units above the fire compartment quickly grow and reach the limit of untenable conditions.

c. In the high wind speed scenario, the smoke of fire grows horizontally through the opening of windows and door headed to the corridor and the void, so that the smoke easily spreads and fills corridors on other floors. Although the spread of the smoke in the corridor has not caused the temperature and the toxic gas FED reaching untenable condition, it inhibits occupants to evacuate due to limited visibility and health problem (from sensory irritation to severe pain and breathing difficulties).

d. In all simulation scenarios, an untenable condition in the fire compartment is reached at a time range between 96 to 105 seconds, around the second minute, after the fire ignites. These results indicate that the occupants in the fire compartment need a fast response time to immediately evacuate.

e. The fire that occurs in the residential unit next to the exit staircase can cause the staircase cannot be used by occupants to evacuate due to smoke spread, temperature and toxic gas FED growth and visibility limit which are dangerous for the occupants. The occupants must use another further staircase to get out of the building. 
Performance-Based Fire Safety in an Existing Residential

Multi-Story Building in Surakarta

Wahyu Sujatmiko, Yulia Rahmawati, Ramadan Pratama

Figure 11. Temperature distribution at $\mathrm{t}=180 \mathrm{~s}$ (Occupied level) Source: Author

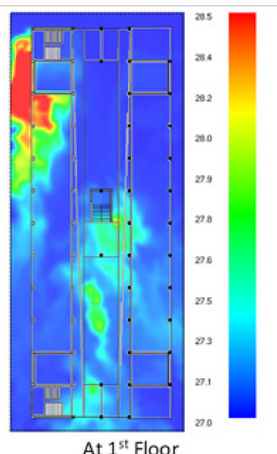

At $1^{\text {st }}$ Floor

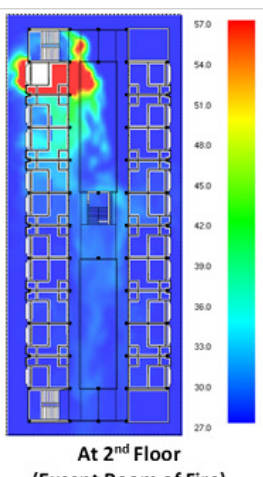

(Except Room of Fire)

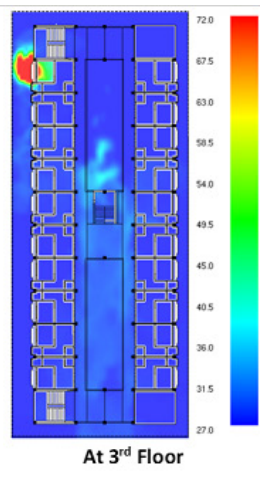

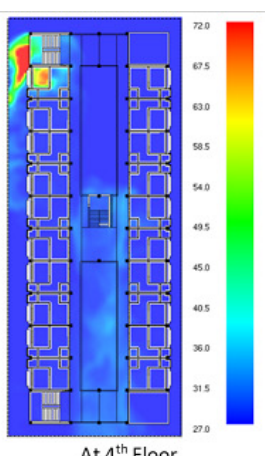

At $4^{\text {th }}$ Floor

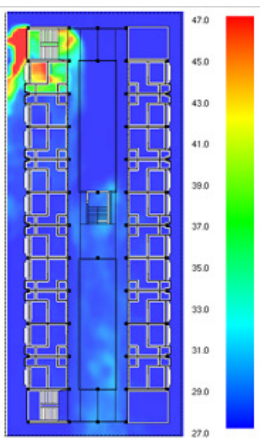

At $5^{\text {th }}$ Floor

Figure 12. Temperature distribution at $\mathrm{t}=180 \mathrm{~s}$ (Occupied level) Source: Author

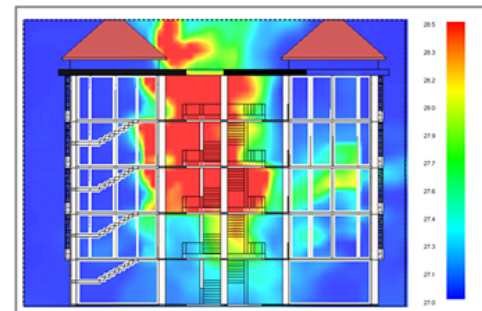

Stair 1 (South Corridor)

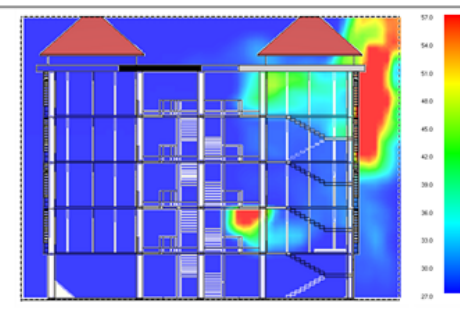

Stair 2 (North Corridor)

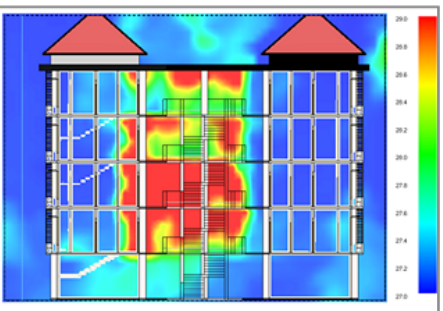

Stair 3 (Mid Corridor)

Figure 13. Wind velocity distribution at $\mathrm{t}=180 \mathrm{~s}$ (Occupied level)

Source: Author

(2)

Figure 14. Smoke Spread

Source: Author
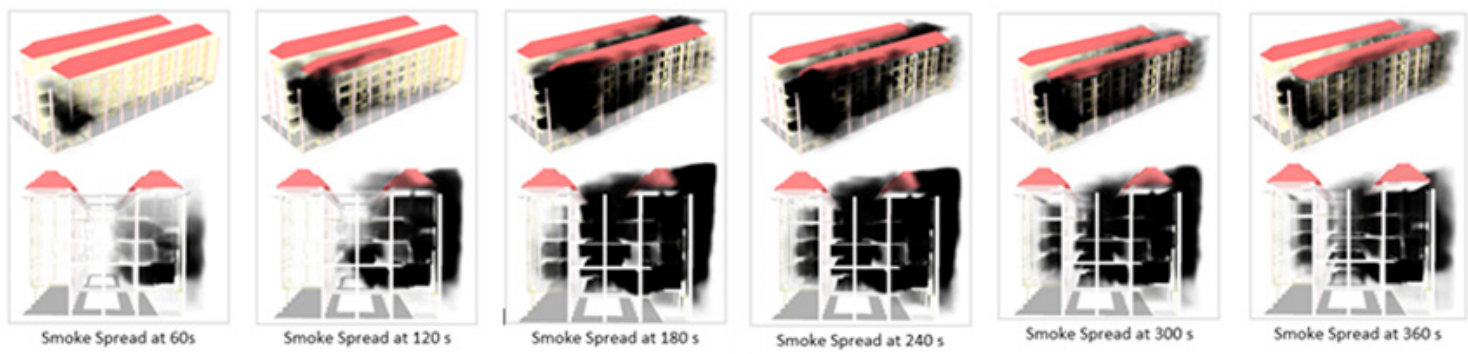
Chart 2. Room of fire temperature development in condition (a) no wind), with wind $0.5 \mathrm{~m} / \mathrm{s}$, (c) with wind $2 \mathrm{~m} / \mathrm{s}$, and (d) wind $5 \mathrm{~m} / \mathrm{s}$

Source: Author

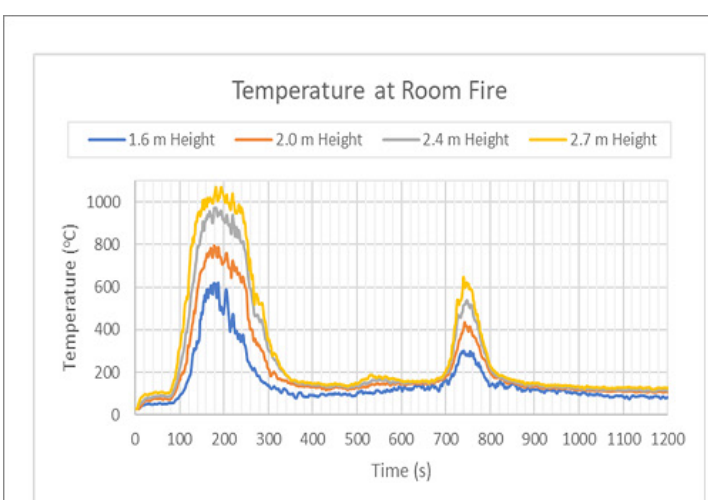

(a)

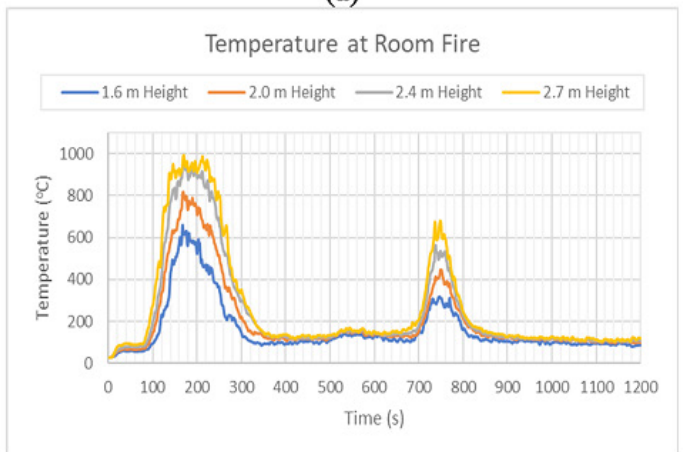

(c)

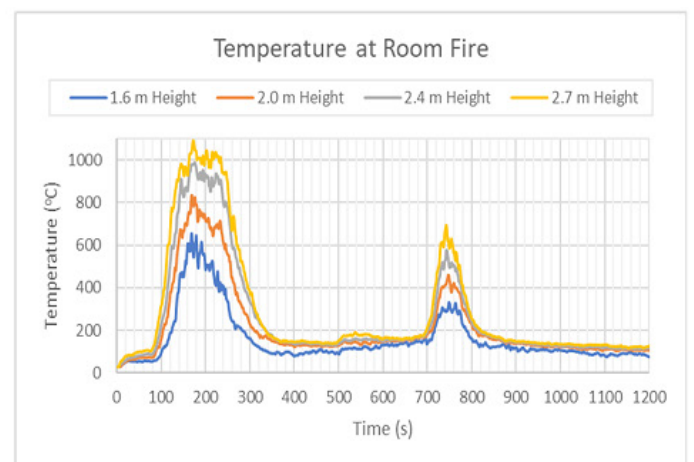

(b)

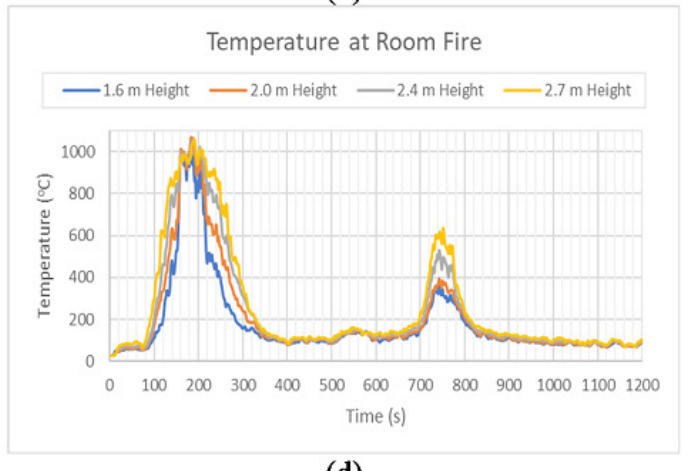

(d)

Chart 3. Gas fractional dose development in various condition.

Source: Author

Toxic Gas FED at Room Fire in Various Wind Speed

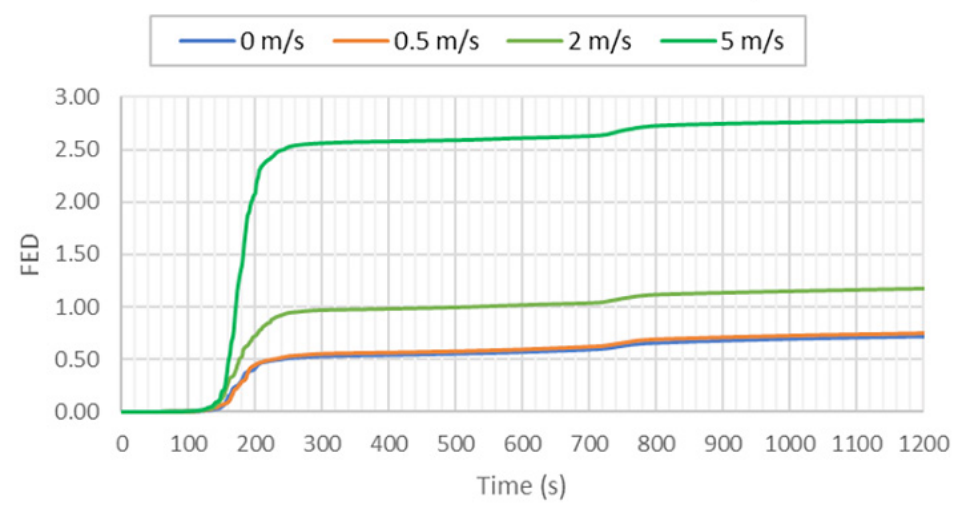

Table 2. Comparison Analysis in Various Condition

\begin{tabular}{lcccc}
\hline \multicolumn{1}{c}{ Parameter at Room of Fire } & \multicolumn{4}{c}{ Condition } \\
\cline { 2 - 5 } & No Wind & Wind $\mathbf{0 . 5} \mathbf{~ m} / \mathbf{s}$ & Wind $\mathbf{2 ~ m / s}$ & Wind $\mathbf{5} \mathbf{~ m} / \mathbf{s}$ \\
\hline Fire HRR max & $5698 \mathrm{~kW}$ & $5725 \mathrm{~kW}$ & $5634 \mathrm{~kW}$ & $5690 \mathrm{~kW}$ \\
& at $164 \mathrm{~s}$ & at $165 \mathrm{~s}$ & at $167 \mathrm{~s}$ & at $164 \mathrm{~s}$ \\
Peak temperature at occupied level & $621^{\circ} \mathrm{C}$ & $654^{\circ} \mathrm{C}$ & $660^{\circ} \mathrm{C}$ & $1047^{\circ} \mathrm{C}$ \\
& at $177 \mathrm{~s}$ & at $168 \mathrm{~s}$ & at $167 \mathrm{~s}$ & at $182 \mathrm{~s}$ \\
Temp. reach $100^{\circ} \mathrm{C}$ at occupied level in & $105 \mathrm{~s}$ & $101 \mathrm{~s}$ & $102 \mathrm{~s}$ & $96 \mathrm{~s}$ \\
FED reach 0.5 at occupied level in & $230 \mathrm{~s}$ & $222 \mathrm{~s}$ & $176 \mathrm{~s}$ & $161 \mathrm{~s}$ \\
\hline
\end{tabular}

Source: Author 
Performance-Based Fire Safety in an Existing Residential Multi-Story Building in Surakarta Wahyu Sujatmiko, Yulia Rahmawati, Ramadan Pratama Gumilar

\section{Results of Evacuation Simulations}

Based on the simulation result, 320 occupants in the building evacuate to the nearest exit staircase from their unit residential. The short distance to the exit staircase affects the rapid evacuation time that is 2.27 minutes or 136 seconds to evacuate 320 people in the building. The other scenario is only the middle exit staircase used from 3 exit staircases existed. There is a cumulation of occupants who are trying to evacuate through the middle exit so that the RSET will be longer that is 5.13 minutes or 313 seconds.

Table 3. Evacuation Simulation Results

\begin{tabular}{ccc}
\hline $\begin{array}{c}\text { Number of } \\
\text { Staircases }\end{array}$ & $\begin{array}{c}\text { Number of } \\
\text { Occupants }\end{array}$ & $\begin{array}{c}\text { Evacuation } \\
\text { Time (second) }\end{array}$ \\
\hline 1 & 320 & 313 \\
3 & 320 & 136 \\
\hline
\end{tabular}

Source: Author

\section{Fire Protection Needs}

Noting the growing danger and the time needed for an evacuation, comparing ASET to RSET, it appears that the flats are essential to be equipped with fire detectors. Detection and alarm systems will be able to help residents awake and evacuate during a fire emergency.

\section{Conclusion}

Based on the results of fire simulations and evacuation simulations, the growth of fire hazard needs to be suppressed to provide sufficient ASET time for residents to evacuate and to shorten RSET time by providing safe evacuation routes for residents. It can be suppressed by providing a minimum active fire protection system such as providing fire alarms for early detection and placing fire extinguishers next to visible area. Therefore, the existing active fire protection of Rusunawa A must be repaired and improved.

The typology of Rusunawa A that tends to be open makes the smoke of fire easy to spread and endangers residents in other areas. Architects and engineers should pay more attention to the design in the early stages of planning.

Fire safety in Rusunawa A can also be improved by good fire safety management such as limiting fire loads, arranging evacuation routes in buildings, conducting evacuation drills, and cooperating with city fire departments.

\section{Acknowledgment}

Thank you to Research Institute for Housing and Human Settlements at the Ministry of Public Works and Housing, Indonesia for their support of survey object building in Surakarta and computer simulations and evacuations with computer cluster facilities.

\section{References}

Blocken, B., Defraeye, T., Derome, D., and Carmeliet, J. (2009). High-resolution CFD simulations for forced convective heat transfer coefficients at the facade of a lowrise building. Building and Environment., vol. 44, no. 12, pp. 2396-2412.

Kim, H.-J. and Lilley, D. G. (2008). Heat Release Rates of Burning Items in Fires. Journal of Propulsion and Power, vol. 18, no. 4, pp. 866-870.

Mcdermott, H., Haslam, R., and Gibb, A. (2010). Occupant interactions with self-closing fire doors in private dwellings. Safety Science, vol. 48, no. 10, pp. 1345-1350.

Liu, J. and Chow, W. K. (2014). Determination of fire load and heat release rate for high-rise residential buildings. Procedia Engineering, vol. 84, pp. 491-497.

Xin, J. and Huang, C. (2013). Fire risk analysis of residential buildings based on scenario clusters and its application in fire risk management. Fire Safety Journal, vol. 62, pp. 72-78.

Kementerian Pekerjaan Umum dan Perumahan Rakyat, Indonesia. (2018). Laporan Akhir Kegiatan APBN 2018. Puslitbang Perumahan dan Permukiman, Badan Litbang.

Kementerian Pekerjaan Umum dan Perumahan Rakyat, Indonesia. (2019). Tipologi Rumah Susun 2019. Direktorat Rumah Susun, Direktorat Jenderal Penyediaan Perumahan.

Spearpoint, M. J., Tohir, M. Z. M., Abu, A. K. and Xie, P. (2015). Fire load energy densities for risk-based design of car parking buildings. Case Studies in Fire Safety, vol. 3, pp. 44-50.

Mckenna, S. T., et al. (2019). Fire behaviour of modern façade materials - Understanding the Grenfell Tower fire. Journal of Hazardous Materials, vol. 368, no. September 2018, 
pp. 115-123.

Baalisampang, T., Abbassi, R., Garaniya, V., Khan, F., and Dadashzadeh, M. (2017) Fire impact assessment in FLNG processing facilities using Computational Fluid Dynamics (CFD). Fire Safety Journal, vol. 92, no. May, pp. 42-52.

Chow, W. K. (2015). Performance-based approach to determining fire safety provisions for buildings in the Asia-Oceania regions. Building and Environtment, vol. 91, pp. 127-137.

Li, W., et al. (2017). Modeling, simulation, and analysis of the evacuation process on stairs in a multi-floor classroom building of a primary. Physica A: Statistical Mechanics and its Applications, vol. 469, pp. 157-172.

Sujatmiko, W. (2016). Penerapan Standar Keselamatan Evakuasi Kebakaran pada Bangunan Gedung di Indonesia. Jurnal Permukiman, vol. 11, no. 2, pp. 116-127.

Sujatmiko, W., Dipojono, H. K., and Soelami, F. X. N. (2014). Performance-based fire safety evacuation in high-rise building flats in Indonesia - a case study in Bandung. Procedia Environmental Science, vol. 20, pp. 116-125.

Deckers, X., Haga, S., Tilley, N., and Merci, B. (2013). Smoke control in case of fire in a large car park: CFD simulations of fullscale configurations. Fire Safety Journal, vol. 57, pp. 22-34.

Fang, Z., et al. (2012). Experimental study on evacuation process in a stairwell of a highrise building. Building and Environment., vol. 47, pp. 316-321. 